\title{
Metodyka kontrolowania związków aminowych i lateksów w płuczkach wiertniczych
}

\section{Methodology of controlling amino compounds and latex in drilling muds}

\author{
Grzegorz Zima \\ Instytut Nafty i Gazu - Państwowy Instytut Badawczy
}

\begin{abstract}
STRESZCZENIE: Obecnie w praktyce przemysłowej w składach płuczek wiertniczych coraz częściej są stosowane inhibitory hydratacji skał zaliczane do związków aminowych. Dla tego typu związków nie opracowano dotychczas metodyki oznaczania ich zawartości w płuczce wiertniczej, a prawidłowe serwisowanie tego rodzaju płuczek wymaga ciągłego kontrolowania ich zawartości celem zapewnienia odpowiednich właściwości inhibicyjnych. Podczas wiercenia związki aminowe adsorbują się na powierzchni skał i ich stężenie ulega zmniejszeniu, co skutkuje obniżeniem inhibicyjnych właściwości płuczki. Często stosowanym w składach płuczek dodatkiem jest lateks, którego oznaczanie jest niezbędne do zapewnienia stabilności parametrów płuczki. Związki tego typu zapewniają utrzymanie stateczności ścian otworu wiertniczego, a ich zawartość również ulega zmniejszeniu podczas głębienia otworu. Uzyskane w opisanych w artykule badaniach wyniki pozwoliły na zaproponowanie metod oznaczania związków aminowych i lateksów. Metody te mogą być wykorzystane w laboratorium polowym podczas serwisowania płuczek wiertniczych. W artykule przedstawiono metodykę oznaczania zawartości nowych rodzajów środków chemicznych stosowanych do płuczek wiertniczych, tj. inhibitorów hydratacji skał zaliczanych do związków aminowych oraz lateksów. Zaproponowane metody umożliwiają prawidłowe serwisowanie płuczek z dodatkiem tych środków, zapewniające utrzymanie odpowiednich właściwości płuczek. Metoda oznaczania związków aminowych polega na określeniu całkowitej zawartości azotu w filtracie płuczki wiertniczej. Rozcieńczenie filtratu pozwala na uzyskanie wyników w zakresie pomiarowym metody i obniżenie stężenia jonów chlorkowych, których ilość nie może przekraczać $10000 \mathrm{mg} / \mathrm{dm}^{3}$. Pierwsza z metod oznaczania lateksu polega na wagowym oznaczeniu suchej pozostałości po wydzieleniu lateksu z filtratu płuczkowego acetonem. Druga natomiast opiera się na pomiarach nefelometrycznych rozcieńczonego dziesięciokrotnie filtratu. Wynikiem pomiaru jest wartość NTU (ang. nephelometric turbidity unit - nefelometryczna jednostka mętności) zależna od zawartości lateksu w filtracie. Wszystkie z opracowanych metod wymagają sporządzenia krzywych wzorcowych, które stanowią podstawę do obliczania zawartości danego środka w płuczce.
\end{abstract}

Słowa kluczowe: płuczka wiertnicza, poliamina, amina, lateks, skała ilasta, inhibitory hydratacji.

ABSTRACT: In industrial practice, rock hydration inhibitors, classified as amine compounds, are being increasingly used in drilling mud compositions. There is no methodology for determining this type of compounds content in the drilling mud, and proper servicing of this type of muds requires constant monitoring of their content to ensure appropriate inhibitory properties. During drilling, amine compounds adsorb on the surface of rocks and their concentration decreases during drilling and reduces the inhibitory properties of the mud. A common additive used in the composition of drilling muds is latex, the determination of which is necessary to ensure the mud parameters stability. Compounds of this type ensure the stability of the borehole wall, while their content also decreases during drilling. The results obtained from the research presented in the article allowed to propose methods for the determination of amine compounds and latexes. These methods can be used in the field laboratory when servicing drilling muds. The article presents the methodology for determining the content of new types of chemicals used in drilling muds, i.e. rock hydration inhibitors classified as amine compounds and latexes. The proposed methods enable proper servicing of muds with the addition of the agents that ensure the maintenance of appropriate mud properties. The method for the determination of amine compounds consists in determining the total nitrogen in the drilling mud filtrate. Dilution of the filtrate provides the results within the measuring range of the method and reduces the concentration of chloride ions, the amount of which may not exceed $10000 \mathrm{mg} / \mathrm{dm}^{3}$. The first method of latex determination is weight determination of the dry residue after separation of the latex from the filtrate with acetone. The second one is based on nephelometric measurements of a tenfold diluted filtrate. The measurement result is the NTU (nephelometric turbidity unit) value depending on the latex content in the filtrate. All of the developed methods require the preparation of calibration curves, which are the basis for calculating the content of a given agent in the mud.

Key words: drilling fluid, polyamine, amine, latex, clay rock, hydration inhibitors.

Autor do korespondencji: G. Zima, e-mail: grzegorz.zima@inig.pl

Artykuł nadesłano do Redakcji: 24.11.2020 r. Zatwierdzono do druku: 03.03.2021 r. 


\section{Wstęp}

Związki aminowe i lateksy są środkami od niedawna stosowanymi na większą skalę $\mathrm{w}$ technologii płuczek wiertniczych. Związki zawierające grupy aminowe wykorzystuje się jako inhibitory nowej generacji ograniczające hydratację skał, zastępujące poliglikol, lub używa się ich w połączeniu z nim w składach płuczek potrójnie inhibitowanych. Ze względu na konieczność kontrolowania właściwości inhibicyjnych płuczek w czasie wiercenia - istnieje potrzeba zastosowania odpowiedniej metodyki oznaczania związków aminowych. Metodyka ta musi uwzględniać możliwości laboratorium polowego na wiertni oraz występowanie w składzie płuczek wiertniczych pozostałych jej składników.

Lateksy są stosowane w składach płuczek wiertniczych celem zapewnienia uszczelnienia przestrzeni porowej skał i ograniczenia wnikania filtratu w przewiercane skały. W czasie wiercenia ich zawartość w płuczce również ulega zmniejszeniu. Prawidłowe uzupełnianie zawartości lateksu i utrzymywanie stabilnych właściwości płuczki wymaga kontrolowania jego stężenia. W artykule zaproponowano metodę z wykorzystaniem selektywnego rozpuszczalnika, który umożliwia wydzielenie lateksu z płuczki i oznaczenie jego zawartości metodami wagowymi. Została również zaproponowana metoda instrumentalna opierająca się na pomiarze mętności filtratu płuczkowego.

\section{Część teoretyczna}

Dane literaturowe (Bielewicz i Bortel, 2000; Bielewicz et al., 2003a, 2003b; van Oort, 2003; Dye et al., 2004, 2005; Al-Ansari et al., 2005; Zhong, 2011; Balaban et al., 2015; Huang et al., 2017) $\mathrm{z}$ ostatnich lat $w$ szerokim zakresie dotyczą stosowania polielektrolitów hydrofilowych z grupami aminowymi. Polimery z grupami aminowymi, głównie pierwszorzędowymi, które są bardziej reaktywne niż polimery z grupami amidowymi, można na wiele sposobów modyfikować chemicznie, otrzymując związki o różnych masach cząsteczkowych, gęstości ładunku i ich rozkładu wzdłuż łańcucha. Pozwoliło to na opracowanie nowego rodzaju płuczki wiertniczej, przeznaczonej głównie do stabilizacji nietrwałych warstw ilastych. Skuteczność inhibicyjnego działania takich polielektrolitów na powierzchnię minerałów ilastych jest wynikiem oddziaływań elektrostatycznych pomiędzy dodatnio naładowanymi ich grupami funkcyjnymi a ujemnie naładowaną powierzchnią skały. Drugi mechanizm inhibitowania polega na zastępowaniu w przestrzeniach międzypakietowych minerałów ilastych kationów wymiennych (nieorganicznych) kationami organicznymi.

W technologii płuczek wiertniczych zastosowanie znalazły polimery syntetyczne zawierające grupy aminowe - jako kationowe środki powierzchniowo czynne i inhibitory hydratacji skał ilastych (Bielewicz i Bortel, 2000; Bortel et al., 2003, 2005, 2007; Wysocki et al. 2007; Uliasz, 2011; Zhang et al., 2016; Uliasz et al., 2018).

Kationowych środków powierzchniowo czynnych używano do olejofilizacji bentonitu przeznaczonego do sporządzania płuczek olejowych. Taka obróbka chemiczna iłu pozwalała na jego dyspersję w rozpuszczalnikach organicznych, natomiast zapobiegała jego dyspersji w wodzie. Dało to podstawę do przeprowadzenia badań z zastosowaniem środków powierzchniowo czynnych w charakterze inhibitorów hydratacji skał ilastych. Badania te miały wpływ na dalsze prace badawcze zmierzające w kierunku zmniejszania pęcznienia i dyspersji skał ilastych przez stosowanie innych odmian polimerów kationowych (Bielewicz i Bortel, 2000; Janota et al., 2002; Fernandez, 2005; Uliasz, 2011; Uliasz et al., 2018).

Pod koniec lat osiemdziesiątych ubiegłego wieku opatentowano czwartorzędową alkiloaminę - chlorek tetrametyloamoniowy jako substytut $\mathrm{KCl}$. Kolejnym związkiem aminowym uznawanym za substytut $\mathrm{KCl}$ była czwartorzędowa hydroksyamina - chlorek $\beta$-hydroksyetylenotrimetyloamoniowy (Schlemmer et al., 2003).

W wyniku kolejnych badań opracowano i z powodzeniem zastosowano w warunkach otworowych poliaminoglikole. Zastosowanie tych środków w środowisku płuczki wiertniczej nie wymagało dodatku $\mathrm{KCl}$ w przeciwieństwie do płuczki obrobionej glikolem. Kolejnym związkiem aminowym jest polieteroamina. Jest to terpolimer o krótkim łańcuchu polimerowym, niewielkiej kationowości i niskiej toksyczności, który zapobiega pęcznieniu skał ilastych, a przy odpowiednim ciężarze cząsteczkowym może być także wykorzystany jako dodatek regulujący filtrację płuczki. Opracowana z jego udziałem płuczka wiertnicza na osnowie wody słodkiej i zasolonej $\mathrm{NaCl}$ została zastosowana na kilku otworach w Zatoce Meksykańskiej (Schlemmer et al., 2003; Young i Stamatakis, 2006; Deville et al., 2011; Uliasz, 2011; Chu et al., 2019).

W wyniku badań nad syntezą polimerów rozpuszczalnych w wodzie opracowane zostały poliaminokwasy amfoteryczne, których makrocząsteczki posiadają równocześnie dodatnie i ujemne ładunki pochodzące od grupy aminowej i karboksylowej. Ze względu na małe rozmiary cząsteczki i amfoteryczny charakter wykazują one dużą zdolność do ograniczania pęcznienia skał czułych na wodę (Patel et al., 2001; Uliasz, 2011).

Jednym ze sposobów zwiększania stabilności formacji łupkowych jest stosowanie w składach płuczek wiertniczych emulsji lateksowych (Huang i Ghassemi, 2010; Al-Muhailan et al., 2014; Liu J. et al., 2014, 2015; Liu C. et al., 2017; Błaż, 2018). Lateks jest wodną zawiesiną polimeru węglowodorowego występującą naturalnie w niektórych gatunkach drzew lub wytworzoną syntetycznie. Koloidalny roztwór kauczuku naturalnego 
otrzymywany jest poprzez nacinanie roślin kauczukodajnych i obróbkę soku mlecznego. Natomiast lateks syntetyczny to wodna dyspersja otrzymywana w technologii kopolimeryzacji emulsyjnej kopolimeru butadienowo-styrenowego, polimetakrylanu metylu, polietylenu, kopolimeru polioctanu winylu, kopolimeru polioctanu winylu, kopolimeru chlorku winylu, polioctanu winylu, polidimetylosiloksanu lub innych. W zależności od zastosowania lateks może zawierać różne dodatki modyfikujące. Emulsje lateksowe od wielu lat są z powodzeniem wykorzystywane w składach zaczynów cementowych. Lateks w zaczynie cementowym służy głównie do kontroli filtracji oraz ograniczania migracji gazu. Tworzy on nieprzepuszczalną barierę, która zapobiega migracji gazu do zaczynu cementowego w okresie hydratacji (Rzymski, 2012; Liu J. et al., 2014, 2015).

W składach płuczek wiertniczych dodatek lateksu wpływa na zmniejszenie filtracji poprzez wytwarzanie na powierzchni skał łupkowych odkształcalnego uszczelnienia. Uszczelnienie jest uważane za półprzepuszczalne, które częściowo blokuje przenikanie filtratu płuczki wiertniczej w matrycę skały, wpływając na zmianę ciśnienia osmotycznego. W niektórych przypadkach lateks dodawany do płuczki wiertniczej łącznie z kompleksem glinowym może wpływać na zmniejszenie przenikania ciśnienia porowego skał łupkowych. Ograniczenie wzrostu ciśnienia, pod jakim płuczka wiertnicza wnika w matrycę skały łupkowej, jest jednym z ważniejszych czynników decydujących o zachowaniu stabilności ścian otworu wiertniczego (Wu et al., 2006; Vickers et al., 2007; Onuoha et al., 2011; Witthayapanyanon et al., 2013; Chao et al., 2014; Rea et al., 2016; Yadav et al., 2016).

\section{Część doświadczalna i metodyka badań}

Wykonane badania miały na celu opracowanie metodyki oznaczania zawartości dwóch rodzajów środków: związków aminowych i lateksów. Związki te zostały wprowadzone do praktyki przemysłowej w ostatnich latach. Głównym czynnikiem wpływającym na obniżanie ich zawartości są zwierciny przedostające się do płuczki podczas głębienia otworu oraz zjawisko adsorpcji lub osadzania na ścianie otworu. Związki te zaadsorbowane na zwiercinach są usuwane z płuczki w procesie jej oczyszczania z urobku. Utrzymanie odpowiedniego stężenia lateksów i związków aminowych w płuczce jest niezbędne do zapewnienia odpowiedniego poziomu inhibicji, a w konsekwencji do bezawaryjnego wiercenia. Przy opracowywaniu metodyki oznaczania tych związków najważniejszym zagadnieniem było wykazanie, że jest możliwe uzyskanie zależności pomiędzy mierzonym parametrem a zawartością środka w płuczce.

Do oznaczania związków aminowych zaproponowano metodę polegającą na oznaczaniu zawartości azotu całkowitego w płuczce wiertniczej lub filtracie płuczkowym. Zastosowanie takiej metodyki jest możliwe ze względu na fakt, że w płuczkach wiertniczych nie wykorzystuje się innych związków zawierających azot $\mathrm{z}$ wyjątkiem PHPA (częściowo hydrolizowanego akryloamidu). PHPA jest używany powszechnie, ale nie stosuje się go zazwyczaj w płuczkach z dodatkiem związków aminowych. Jest to więc pewne ograniczenie w stosowalności tej metody. W płuczce może występować pewna ilość azotu, np. pochodzącego z wody użytej do sporządzania płuczki, ale jest to ilość nieznaczna przy dodatku związku aminowego do płuczki i jest to zazwyczaj wartość w przybliżeniu stała.

Metoda zaproponowana w niniejszej pracy opiera się na gotowych testach probówkowych, do których potrzebny jest dodatkowo fotometr i termostat do mineralizacji próbek. Przed wykonaniem testu istnieje tylko potrzeba rozcieńczenia próbki i uregulowania pH do odpowiedniego zakresu. Wynik pomiaru otrzymujemy w miligramach azotu, który należy przeliczyć z krzywej wzorcowej na zawartość związku aminowego w płuczce. Równanie uzyskujemy przez sporządzenie krzywej wzorcowej dla roztworów o znanych stężeniach.

Lateksy można wydzielić z zawiesin wodnych za pomocą niektórych rozpuszczalników organicznych. W opracowanej metodzie wykorzystano aceton, który powoduje wydzielenie lateksu w postaci zlepionych kłaczków. Wydzielony w ten sposób lateks łatwo oddziela się od fazy wodnej. Warunkiem stosowania tej metody jest wykorzystanie do oznaczenia filtratu z płuczki, ponieważ aceton nie działa selektywnie i powoduje również wydzielenie koloidów ochronnych znajdujących się w płuczce. Wydzielony z filtratu lateks należy wysuszyć na łaźni wodnej do stałej masy. Ilość środka lateksowego w płuczce należy obliczyć z krzywej wzorcowej sporządzonej dla wodnych roztworów o znanych stężeniach.

W ramach pracy zaproponowano również alternatywną metodę oznaczania lateksu w filtracie płuczkowym, która opiera się na pomiarze mętności. Do pomiaru wykorzystano turbidymetr. Pomiary mętności filtratów po rozcieńczeniu pozwoliły uzyskać zależność mętności od stężenia lateksu w płuczce o wyższych koncentracjach lateksu. Zależność mętności filtratu od stężenia lateksu w postaci prostej wzorcowej pozwala na obliczenie zawartości środka lateksowego w płuczce.

Uzyskane zależności, zarówno dla dodatku do płuczek wiertniczych związków aminowych, jak i lateksu, posłużyły do dalszych badań w celu kontrolowania ich zawartości w płuczce. Do płuczek zawierających różne ich ilości dodawano zwierciny i w ten sposób symulowano warunki występujące podczas wiercenia. Otrzymane wyniki pozwoliły na ocenę stopnia zużycia poszczególnych środków podczas wzrastającej zawartości fazy stałej (zwiercin) w płuczce. Do płuczek dodawano kolejno zwierciny w ilości: $1 \%, 2 \%(\Sigma 3 \%)$ i $2 \%$ ( $(\Sigma 5 \%)$ i oznaczano zawartość lateksu lub związku aminowego. 


\section{Badania laboratoryjne nad opracowaniem metodyki oznaczania zwiazków aminowych w płuczkach wiertniczych}

Badania nad zastosowaniem metody oznaczania związków aminowych w płuczkach wiertniczych rozpoczęto od wyznaczenia krzywych wzorcowych dla dwóch wybranych środków. W tym celu sporządzono roztwory wodne środków Aminal i Amina2 o stężeniach $0,5 \%, 1,0 \%, 2,0 \%$ i 3,0\%. Wybrany zakres stężeń odpowiadał zawartościom stosowanym w płuczkach wiertniczych. Dla tak sporządzonych roztworów wyznaczono zależności stężeń środków od oznaczonej zawartości azotu. Zawartość azotu oznaczano dla 10-krotnego rozcieńczenia, co zapewnia uzyskanie wyniku w zakresie pomiarowym. Otrzymane zależności w formie wykresów i równań posłużyły do dalszych badań. Na każdym wykresie oprócz równania umieszczono wartość współczynnika korelacji $\mathrm{R}^{2}$. Dla obu środków uzyskano wartość współczynnika korelacji bliską 1 (tab. 1 i 2 , rys. 1 i 2).

W dalszej części pracy przeprowadzono podobne jak w przypadku wodnych roztworów badania zawartości azotu w płuczkach wiertniczych zawierających środki Amina1 i Amina2. Oznaczenia zawartości azotu wykonano w filtratach płuczek ze względu na konieczność oddzielenia fazy stałej,

Tabela 1. Wyniki oznaczenia zawartości azotu w roztworach środka Aminal

Table 1. Results of nitrogen content determination in solutions of Aminal agent

\begin{tabular}{|c|c|c|c|}
\hline \multirow{2}{*}{$\begin{array}{c}\text { Nr } \\
\text { płuczki }\end{array}$} & \multicolumn{2}{|c|}{ Sklad cieczy } & $\begin{array}{c}\text { Wynik oznaczenia } \\
\text { zawartości azotu }\end{array}$ \\
\cline { 2 - 4 } & \multicolumn{2}{|c|}{$[\%]$} & {$\left[\mathbf{m g} / \mathbf{d m}^{3}\right]$} \\
\hline \hline 1 & Amina1 & 0,5 & 100 \\
\hline 2 & Amina1 & 1,0 & 410 \\
\hline 3 & Amina1 & 2,0 & 1100 \\
\hline 4 & Amina1 & 3,0 & 1860 \\
\hline
\end{tabular}

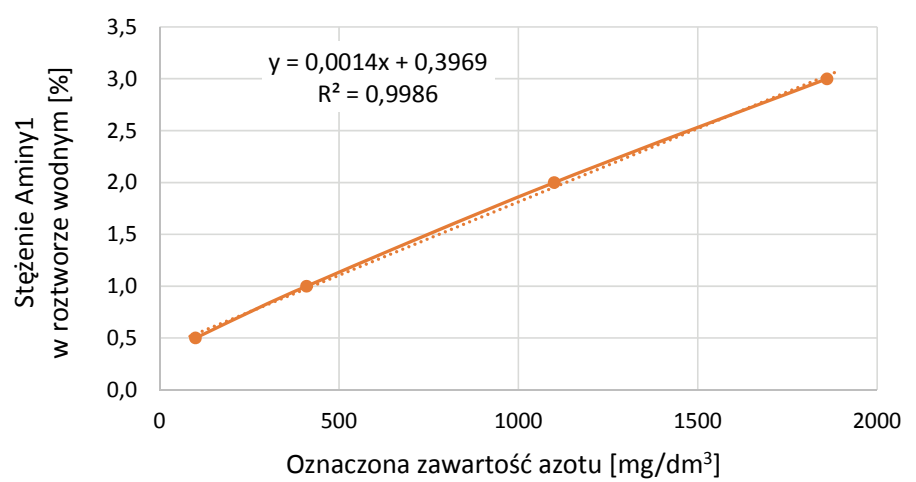

Rys. 1. Zależność zawartości azotu od stężenia środka Aminal w roztworach wodnych

Fig. 1. Dependence of nitrogen content on the concentration of Aminal agent in aqueous solutions na której mogą adsorbować się związki aminowe. Uzyskane wyniki zestawiono w tabelach 3 i 4 oraz na rysunkach 3 i 4 .

\section{Badania laboratoryjne nad opracowaniem metodyki oznaczania lateksów w płuczkach wiertniczych}

Badania nad oznaczaniem lateksów przeprowadzono podobnie jak w przypadku związków aminowych w roztworach wodnych zawierających po $1 \%, 2 \%, 3 \%$ i 5\% środka Lateks 1 lub środka Lateks2. Po przeanalizowaniu właściwości związków zaliczanych do lateksów wybrano dwie metody, które pozwalałyby kontrolować zmiany stężenia tych środków w płuczce. Pierwsza metoda opierała się na wagowym oznaczeniu suchej pozostałości po wydzieleniu lateksu z zawiesiny za pomocą acetonu. Podstawą drugiej metody był pomiar mętności zawiesiny lateksu za pomocą turbidymetru. Wyniki analiz suchej pozostałości po wydzieleniu lateksu z wodnych roztworów za pomocą acetonu zestawiono $w$ tabelach 5 i 6 oraz przedstawiono graficznie na rysunkach 5 i 6 . Wyniki pomiarów mętności wodnych zawiesin po 10-krotnym rozcieńczeniu ujęto $\mathrm{w}$ tabelach 7 i 8 i na rysunkach 7 i 8 .

W kolejnych badaniach przeprowadzono oznaczenia suchej pozostałości uzyskanej po wydzieleniu lateksu z zawiesin

Tabela 2. Wyniki oznaczenia zawartości azotu w roztworach środka Amina2

Table 2. Results of nitrogen content determination in solutions of Amina2 agent

\begin{tabular}{|c|c|c|c|}
\hline \multirow{2}{*}{$\begin{array}{c}\text { Nr } \\
\text { płuczki }\end{array}$} & \multicolumn{2}{|c|}{ Skład cieczy } & $\begin{array}{c}\text { Wynik oznaczenia } \\
\text { zawartości azotu }\end{array}$ \\
\cline { 2 - 4 } & \multicolumn{2}{|c|}{$[\%]$} & {$\left[\mathbf{m g} / \mathbf{d m}^{3}\right]$} \\
\hline \hline 1 & Amina2 & 0,5 & 180 \\
\hline 2 & Amina2 & 1,0 & 280 \\
\hline 3 & Amina2 & 2,0 & 500 \\
\hline 4 & Amina2 & 3,0 & 710 \\
\hline
\end{tabular}

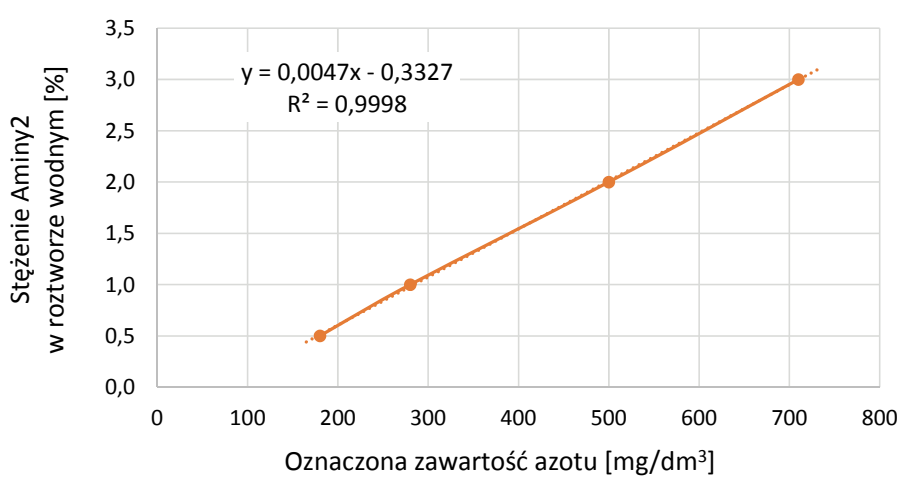

Rys. 2. Zależność zawartości azotu od stężenia środka Amina2 w roztworach wodnych

Fig. 2. Dependence of nitrogen content on the concentration of Amina2 agent in aqueous solutions 
w filtratach płuczek wiertniczych (tab. 9, 10, rys. 9, 10) oraz mętności filtratów (tab. 11, 12, rys. 11, 12). Zależności

Tabela 3. Wyniki oznaczenia zawartości azotu w filtratach płuczek wiertniczych z dodatkiem środka Aminal

Table 3. Results of nitrogen content determination in drilling muds filtrate containing Amina1 agent

\begin{tabular}{|c|c|c|c|}
\hline \multirow{2}{*}{$\begin{array}{c}\mathrm{Nr} \\
\text { płuczki }\end{array}$} & \multicolumn{2}{|c|}{ Skład cieczy } & $\begin{array}{l}\text { Wynik oznaczenia } \\
\text { zawartości azotu }\end{array}$ \\
\hline & \multicolumn{2}{|l|}{$[\%]$} & {$\left[\mathrm{mg} / \mathbf{d m}^{3}\right]$} \\
\hline 1 & $\begin{array}{l}\text { Biocyd } \\
\text { CMC LV } \\
\text { PAC LV } \\
\text { Ksantan } \\
\text { KCl } \\
\text { Blokator węglanowy } \\
\text { Amina1 }\end{array}$ & $\begin{array}{c}0,1 \\
1,8 \\
0,05 \\
0,15 \\
7 \\
7 \\
\mathbf{0 , 5}\end{array}$ & 200 \\
\hline 2 & $\begin{array}{l}\text { Biocyd } \\
\text { CMC LV } \\
\text { PAC LV } \\
\text { Ksantan } \\
\text { KCl } \\
\text { Blokator węglanowy } \\
\text { Amina1 }\end{array}$ & $\begin{array}{c}0,1 \\
1,8 \\
0,05 \\
0,15 \\
7 \\
7 \\
\mathbf{1 , 0}\end{array}$ & 620 \\
\hline 3 & $\begin{array}{l}\text { Biocyd } \\
\text { CMC LV } \\
\text { PAC LV } \\
\text { Ksantan } \\
\text { KCl } \\
\text { Blokator węglanowy } \\
\text { Amina1 }\end{array}$ & $\begin{array}{c}0,1 \\
1,8 \\
0,05 \\
0,15 \\
7 \\
7 \\
\mathbf{2 , 0}\end{array}$ & 1350 \\
\hline 4 & $\begin{array}{l}\text { Biocyd } \\
\text { CMC LV } \\
\text { PAC LV } \\
\text { Ksantan } \\
\text { KCl } \\
\text { Blokator węglanowy } \\
\text { Amina1 }\end{array}$ & $\begin{array}{c}0,1 \\
1,8 \\
0,05 \\
0,15 \\
7 \\
7 \\
\mathbf{3 , 0}\end{array}$ & 2050 \\
\hline
\end{tabular}

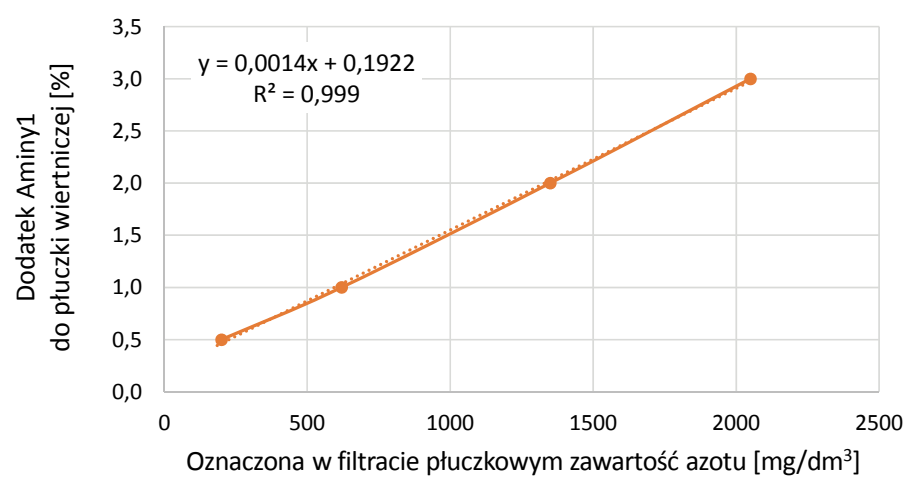

Rys. 3. Zależność zawartości azotu w filtracie płuczkowym od dodatku środka Aminal do płuczki wiertniczej

Fig. 3. Dependence of nitrogen content on Aminal agent in drilling muds filtrate otrzymane dla płuczek mają podobny przebieg jak w przypadku wodnych zawiesin.

Tabela 4. Wyniki oznaczenia zawartości azotu w filtratach płuczek wiertniczych z dodatkiem środka aminowego Amina2

Table 4. Results of nitrogen content determination in drilling muds filtrate containing Amina2 agent

\begin{tabular}{|c|c|c|c|}
\hline \multirow{2}{*}{$\begin{array}{c}\mathrm{Nr} \\
\text { płuczki }\end{array}$} & \multicolumn{2}{|c|}{ Skład cieczy } & $\begin{array}{l}\text { Wynik oznaczenia } \\
\text { zawartości azotu }\end{array}$ \\
\hline & \multicolumn{2}{|l|}{$[\%]$} & {$\left[\mathrm{mg} / \mathrm{dm}^{3}\right]$} \\
\hline 1 & $\begin{array}{l}\text { Biocyd } \\
\text { CMC LV } \\
\text { PAC LV } \\
\text { Ksantan } \\
\text { KCl } \\
\text { Blokator węglanowy } \\
\text { Amina2 }\end{array}$ & $\begin{array}{c}0,1 \\
1,8 \\
0,05 \\
0,2 \\
7 \\
7 \\
\mathbf{0 , 5}\end{array}$ & 240 \\
\hline 2 & $\begin{array}{l}\text { Biocyd } \\
\text { CMC LV } \\
\text { PAC LV } \\
\text { Ksantan } \\
\text { KCl } \\
\text { Blokator węglanowy } \\
\text { Amina2 }\end{array}$ & $\begin{array}{c}0,1 \\
1,8 \\
0,05 \\
0,2 \\
7 \\
7 \\
\mathbf{1 , 0}\end{array}$ & 340 \\
\hline 3 & $\begin{array}{l}\text { Biocyd } \\
\text { CMC LV } \\
\text { PAC LV } \\
\text { Ksantan } \\
\text { KCl } \\
\text { Blokator węglanowy } \\
\text { Amina2 }\end{array}$ & $\begin{array}{c}0,1 \\
1,8 \\
0,05 \\
0,2 \\
7 \\
7 \\
\mathbf{2 , 0}\end{array}$ & 560 \\
\hline 4 & $\begin{array}{l}\text { Biocyd } \\
\text { CMC LV } \\
\text { PAC LV } \\
\text { Ksantan } \\
\mathrm{KCl} \\
\text { Blokator węglanowy } \\
\text { Amina2 }\end{array}$ & $\begin{array}{c}0,1 \\
1,8 \\
0,05 \\
0,2 \\
7 \\
7 \\
\mathbf{3 , 0}\end{array}$ & 770 \\
\hline
\end{tabular}

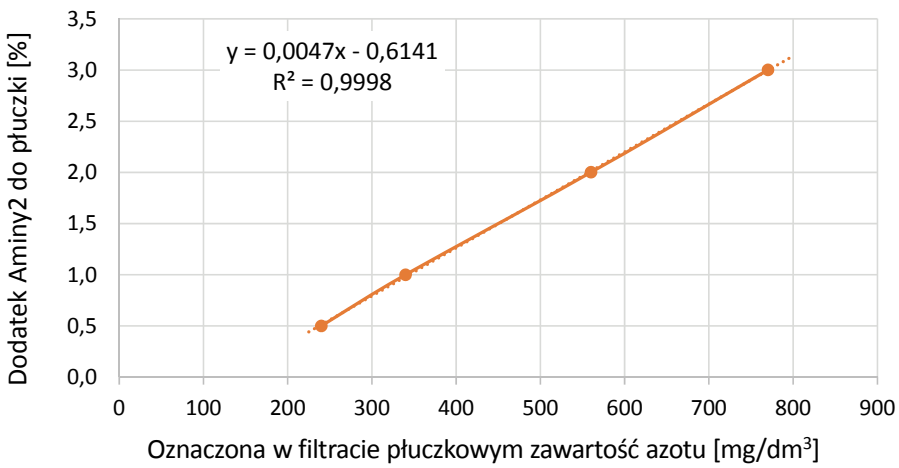

Rys. 4. Zależność zawartości azotu w filtracie płuczkowym od dodatku środka Amina2 do płuczki wiertniczej

Fig. 4. Dependence of nitrogen content on Amina2 agent in drilling muds filtrate 
Tabela 5. Wyniki oznaczenia zawartości suchej pozostałości w zawiesinach Lateksu1

Table 5. Results of the dry residue content determination in Latex1 suspensions

\begin{tabular}{|c|c|c|c|}
\hline \multirow{2}{*}{$\begin{array}{c}\text { Nr } \\
\text { płuczki }\end{array}$} & \multicolumn{2}{|c|}{ Skład cieczy } & $\begin{array}{c}\text { Masa suchej pozostałości } \\
\text { z 10 } \text { cm}^{3} \text { zawiesiny }\end{array}$ \\
\cline { 2 - 4 } & \multicolumn{2}{|c|}{$[\%]$} & [g] \\
\hline \hline 1 & Lateks1 & 1,0 & 0,0199 \\
\hline 2 & Lateks1 & 2,0 & 0,0489 \\
\hline 3 & Lateks1 & 3,0 & 0,7270 \\
\hline 4 & Lateks1 & 5,0 & 0,1128 \\
\hline
\end{tabular}

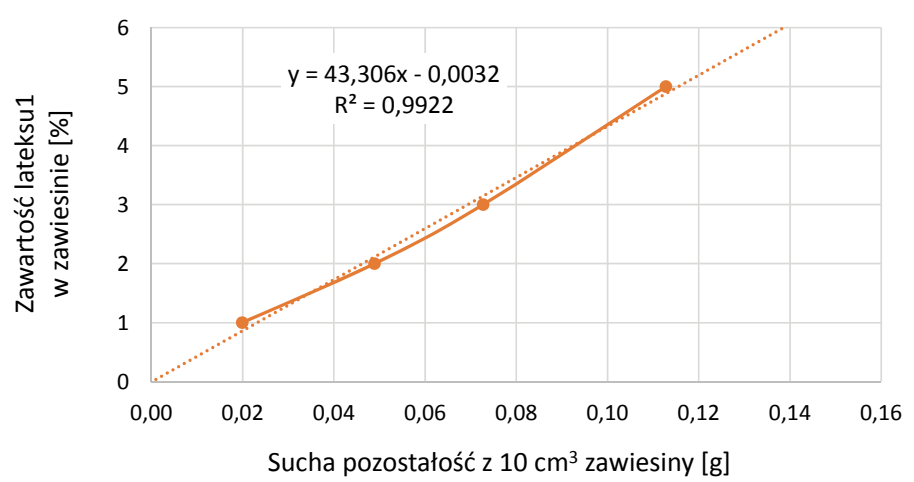

Rys. 5. Zależność suchej pozostałości od zawartości Lateksu1

Fig. 5. Dependence of the dry residue on content Latex 1 in suspensions

Tabela 7. Wyniki pomiarów mętności w zawiesinach Lateksu1

Table 7. Turbidity measurements results in Latex 1 suspensions

\begin{tabular}{|c|c|c|c|}
\hline \multirow{2}{*}{$\begin{array}{c}\text { Nr } \\
\text { płuczki }\end{array}$} & \multicolumn{2}{|c|}{ Skład cieczy } & $\begin{array}{c}\text { Mętność zawiesiny po } \\
\text { 10-krotnym rozcieńczeniu }\end{array}$ \\
\cline { 2 - 4 } & \multicolumn{2}{|c|}{$[\%]$} & [NTU] \\
\hline \hline 1 & Lateks1 & 1,0 & 25 \\
\hline 2 & Lateks1 & 2,0 & 148 \\
\hline 3 & Lateks1 & 3,0 & 373 \\
\hline 4 & Lateks1 & 5,0 & 854 \\
\hline
\end{tabular}

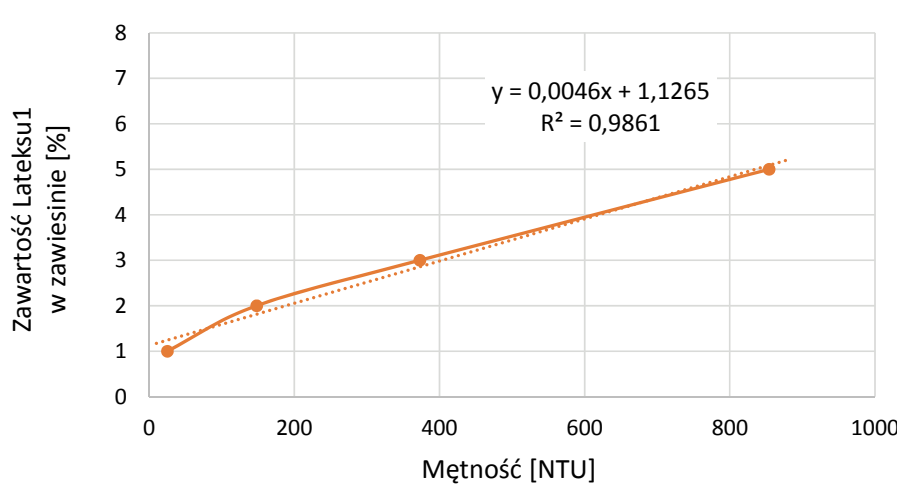

Rys. 7. Zależność mętności 10-krotnie rozcieńczonych roztworów od zawartości Lateksu1

Fig. 7. Dependence of the turbidity of 10 -fold diluted suspensions on Latex 1 content
Tabela 6. Wyniki oznaczenia zawartości suchej pozostałości w zawiesinach Lateksu2

Table 6. Results of the dry residue content determination in Latex2 suspensions

\begin{tabular}{|c|c|c|c|}
\hline \multirow{2}{*}{$\begin{array}{c}\text { Nr } \\
\text { płuczki }\end{array}$} & \multicolumn{2}{|c|}{ Sklad cieczy } & $\begin{array}{c}\text { Masa suchej pozostałości } \\
\text { z 10 } \text { cm}^{\mathbf{3}} \text { zawiesiny }\end{array}$ \\
\cline { 2 - 4 } & \multicolumn{2}{|c|}{$[\%]$} & {$[\mathrm{g}]$} \\
\hline \hline 1 & Lateks2 & 1,0 & 0,0288 \\
\hline 2 & Lateks2 & 2,0 & 0,0648 \\
\hline 3 & Lateks2 & 3,0 & 0,0963 \\
\hline 4 & Lateks2 & 5,0 & 0,1539 \\
\hline
\end{tabular}

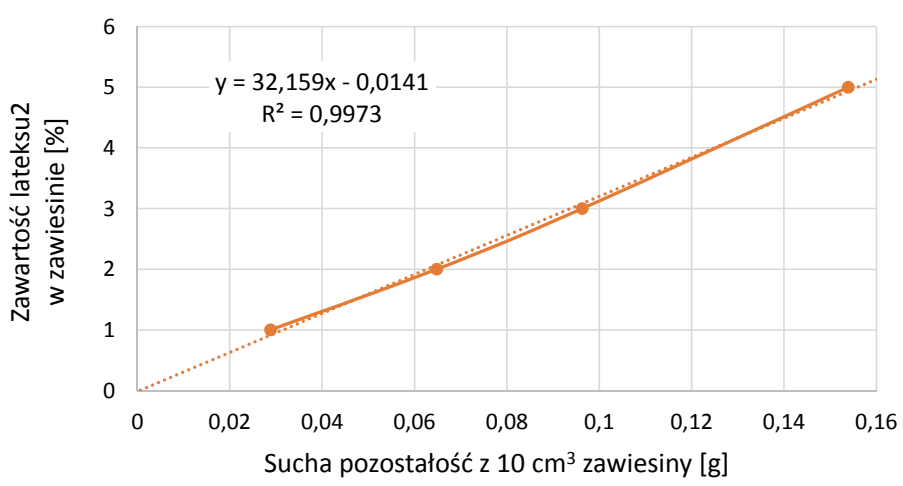

Rys. 6. Zależność suchej pozostałości od zawartości Lateksu2

Fig. 6. Dependence of the dry residue on content Latex 2 in suspensions

Tabela 8. Wyniki pomiarów mętności w zawiesinach Lateksu2

Table 8. Turbidity measurements results in Latex2 suspensions

\begin{tabular}{|c|c|c|c|}
\hline \multirow{2}{*}{$\begin{array}{c}\text { Nr } \\
\text { płuczki }\end{array}$} & \multicolumn{2}{|c|}{ Skład cieczy } & $\begin{array}{c}\text { Mętność zawiesiny po } \\
\text { 10-krotnym rozcieńczeniu }\end{array}$ \\
\cline { 2 - 4 } & {$[\%]$} & & [NTU] \\
\hline \hline 1 & Lateks2 & 1,0 & 36 \\
\hline 2 & Lateks2 & 2,0 & 114 \\
\hline 3 & Lateks2 & 3,0 & 177 \\
\hline 4 & Lateks2 & 5,0 & 286 \\
\hline
\end{tabular}

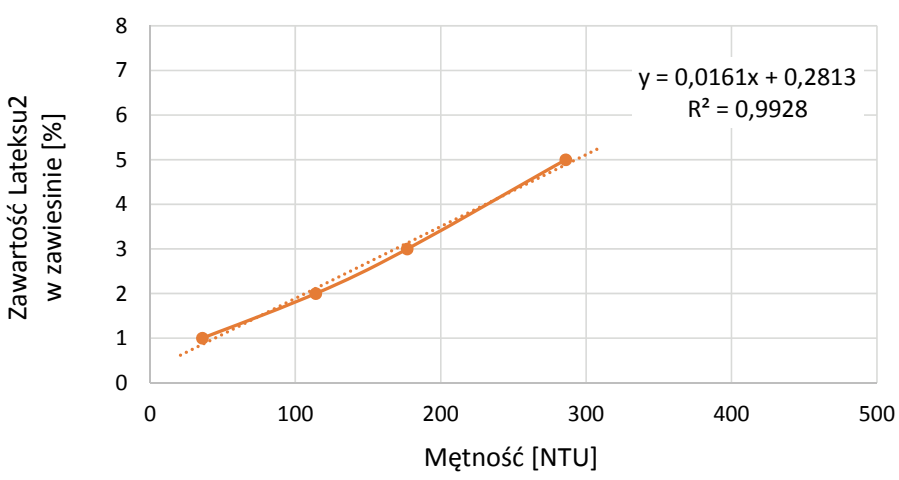

Rys. 8. Zależność mętności 10-krotnie rozcieńczonych roztworów od zawartości Lateksu2

Fig. 8. Dependence of the turbidity of 10 -fold diluted suspensions on Latex 2 content 


\section{NAFTA-GAZ}

Tabela 9. Wyniki oznaczenia zawartości suchej pozostałości w zawiesinach Lateksu1 w filtratach płuczkowych

Table 9. Results of the dry residue content determination in Latex 1 suspensions in the drilling muds filtrate

\begin{tabular}{|c|c|c|c|}
\hline \multirow{2}{*}{$\begin{array}{c}\mathrm{Nr} \\
\text { płuczki }\end{array}$} & \multicolumn{2}{|l|}{ Skład cieczy } & $\begin{array}{l}\text { Masa suchej pozostałości } \\
\text { z } 10 \mathrm{~cm}^{3} \text { zawiesiny }\end{array}$ \\
\hline & \multicolumn{2}{|l|}{ [\%] } & [g] \\
\hline 1 & $\begin{array}{l}\text { Biocyd } \\
\text { CMC LV } \\
\text { PAC LV } \\
\text { Ksantan } \\
\text { KCl } \\
\text { Blokator węglanowy } \\
\text { Lateks1 }\end{array}$ & $\begin{array}{c}0,1 \\
1,8 \\
0,05 \\
0,2 \\
7 \\
7 \\
\mathbf{1}\end{array}$ & 0,0257 \\
\hline 2 & $\begin{array}{l}\text { Biocyd } \\
\text { CMC LV } \\
\text { PAC LV } \\
\text { Ksantan } \\
\text { KCl } \\
\text { Blokator węglanowy } \\
\text { Lateks1 }\end{array}$ & $\begin{array}{c}0,1 \\
1,8 \\
0,05 \\
0,2 \\
7 \\
7 \\
2\end{array}$ & 0,0452 \\
\hline 3 & $\begin{array}{l}\text { Biocyd } \\
\text { CMC LV } \\
\text { PAC LV } \\
\text { Ksantan } \\
\text { KCl } \\
\text { Blokator węglanowy } \\
\text { Lateks1 }\end{array}$ & $\begin{array}{c}0,1 \\
1,8 \\
0,05 \\
0,2 \\
7 \\
7 \\
\mathbf{3}\end{array}$ & 0,0730 \\
\hline 4 & $\begin{array}{l}\text { Biocyd } \\
\text { CMC LV } \\
\text { PAC LV } \\
\text { Ksantan } \\
\text { KCl } \\
\text { Blokator węglanowy } \\
\text { Lateks1 }\end{array}$ & $\begin{array}{c}0,1 \\
1,8 \\
0,05 \\
0,2 \\
7 \\
7 \\
5\end{array}$ & 0,1070 \\
\hline
\end{tabular}

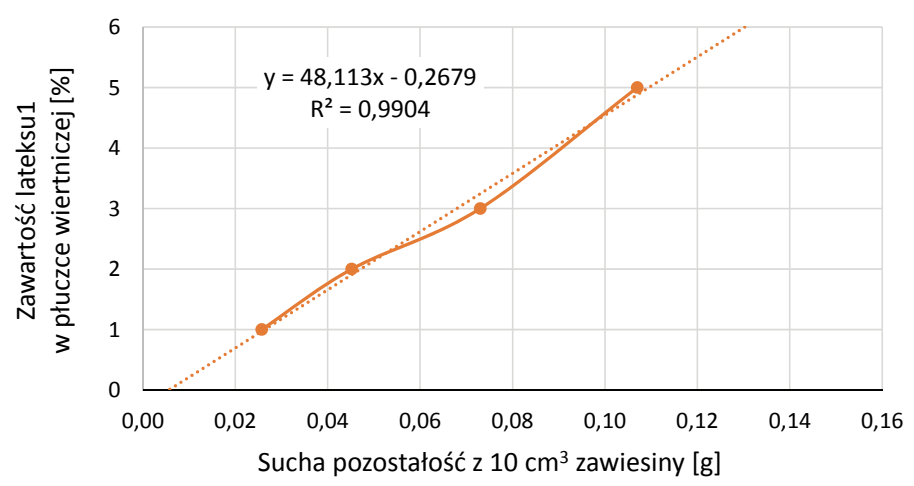

Rys. 9. Zależność suchej pozostałości od zawartości Lateksu1 w filtratach płuczkowych

Fig. 9. Dependence of the dry residue content in Latex1 suspensions in the drilling muds filtrate
Tabela 10. Wyniki oznaczenia zawartości suchej pozostałości w zawiesinach Lateksu2 w filtratach płuczkowych

Table 10. Results of the dry residue content determination in Latex 2 suspensions in the drilling muds filtrate

\begin{tabular}{|c|c|c|c|}
\hline \multirow{2}{*}{$\underset{\text { pluczki }}{\mathrm{Nr}}$} & \multicolumn{2}{|l|}{ Skład cieczy } & $\begin{array}{l}\text { Masa suchej pozostalości } \\
\text { z } 10 \mathrm{~cm}^{3} \text { zawiesiny }\end{array}$ \\
\hline & \multicolumn{2}{|l|}{$[\%]$} & [g] \\
\hline 1 & $\begin{array}{l}\text { Biocyd } \\
\text { CMC LV } \\
\text { PAC LV } \\
\text { Ksantan } \\
\text { KCl } \\
\text { Blokator węglanowy } \\
\text { Lateks2 }\end{array}$ & $\begin{array}{c}0,1 \\
1,8 \\
0,05 \\
0,2 \\
7 \\
7 \\
\mathbf{1}\end{array}$ & 0,0089 \\
\hline 2 & $\begin{array}{l}\text { Biocyd } \\
\text { CMC LV } \\
\text { PAC LV } \\
\text { Ksantan } \\
\text { KCl } \\
\text { Blokator węglanowy } \\
\text { Lateks2 }\end{array}$ & $\begin{array}{c}0,1 \\
1,8 \\
0,05 \\
0,2 \\
7 \\
7 \\
2\end{array}$ & 0,041 \\
\hline 3 & $\begin{array}{l}\text { Biocyd } \\
\text { CMC LV } \\
\text { PAC LV } \\
\text { Ksantan } \\
\text { KCl } \\
\text { Blokator węglanowy } \\
\text { Lateks2 }\end{array}$ & $\begin{array}{c}0,1 \\
1,8 \\
0,05 \\
0,15 \\
7 \\
7 \\
\mathbf{3}\end{array}$ & 0,0733 \\
\hline 4 & $\begin{array}{l}\text { Biocyd } \\
\text { CMC LV } \\
\text { PAC LV } \\
\text { Ksantan } \\
\text { KCl } \\
\text { Blokator węglanowy } \\
\text { Lateks2 }\end{array}$ & $\begin{array}{c}0,1 \\
1,8 \\
0,05 \\
0,2 \\
7 \\
7 \\
\mathbf{5}\end{array}$ & 0,1311 \\
\hline
\end{tabular}

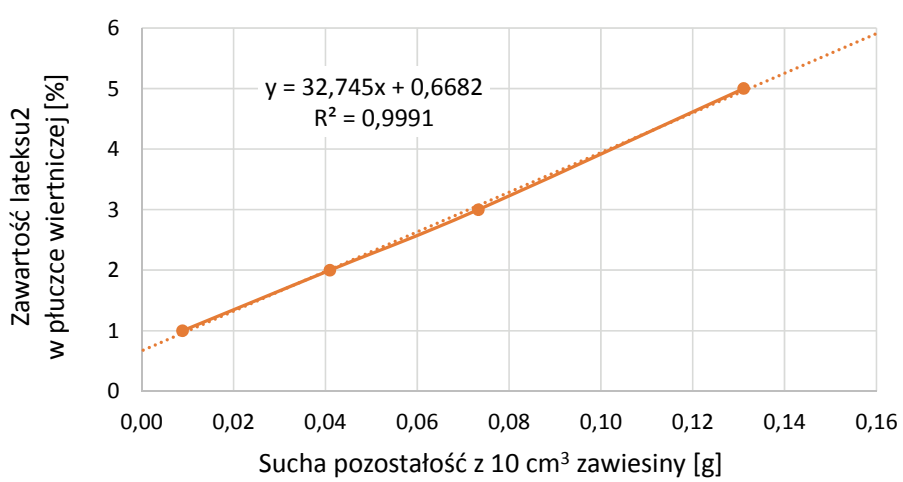

Rys. 10. Zależność suchej pozostałości od zawartości Lateksu2 w filtratach płuczkowych

Fig. 10. Dependence of the dry residue content in Latex2 suspensions in the drilling muds filtrate 
Tabela 11. Wyniki pomiarów mętności w zawiesinach Lateksu1 w filtratach płuczkowych

Table 11. Results of the turbidity measurements in Latex1 suspensions in the drilling muds filtrate

\begin{tabular}{|c|c|c|c|}
\hline \multirow{2}{*}{$\underset{\text { pluczki }}{\mathrm{Nr}}$} & \multicolumn{2}{|l|}{ Sklad cieczy } & Mętność zawiesiny po \\
\hline & \multicolumn{2}{|l|}{ [\%] } & [NTU] \\
\hline 1 & $\begin{array}{l}\text { Biocyd } \\
\text { CMC LV } \\
\text { PAC LV } \\
\text { Ksantan } \\
\text { KCl } \\
\text { Blokator węglanowy } \\
\text { Lateks1 }\end{array}$ & $\begin{array}{c}0,1 \\
1,8 \\
0,05 \\
0,2 \\
7 \\
7 \\
1\end{array}$ & 16 \\
\hline 2 & $\begin{array}{l}\text { Biocyd } \\
\text { CMC LV } \\
\text { PAC LV } \\
\text { Ksantan } \\
\text { KCl } \\
\text { Blokator węglanowy } \\
\text { Lateks1 }\end{array}$ & $\begin{array}{c}0,1 \\
1,8 \\
0,05 \\
0,2 \\
7 \\
7 \\
2\end{array}$ & 98 \\
\hline 3 & $\begin{array}{l}\text { Biocyd } \\
\text { CMC LV } \\
\text { PAC LV } \\
\text { Ksantan } \\
\text { KCl } \\
\text { Blokator węglanowy } \\
\text { Lateks1 }\end{array}$ & $\begin{array}{c}0,1 \\
1,8 \\
0,05 \\
0,2 \\
7 \\
7 \\
\mathbf{3}\end{array}$ & 316 \\
\hline 4 & $\begin{array}{l}\text { Biocyd } \\
\text { CMC LV } \\
\text { PAC LV } \\
\text { Ksantan } \\
\text { KCl } \\
\text { Blokator węglanowy } \\
\text { Lateks1 }\end{array}$ & $\begin{array}{c}0,1 \\
1,8 \\
0,05 \\
0,2 \\
7 \\
7 \\
\mathbf{5}\end{array}$ & 817 \\
\hline
\end{tabular}

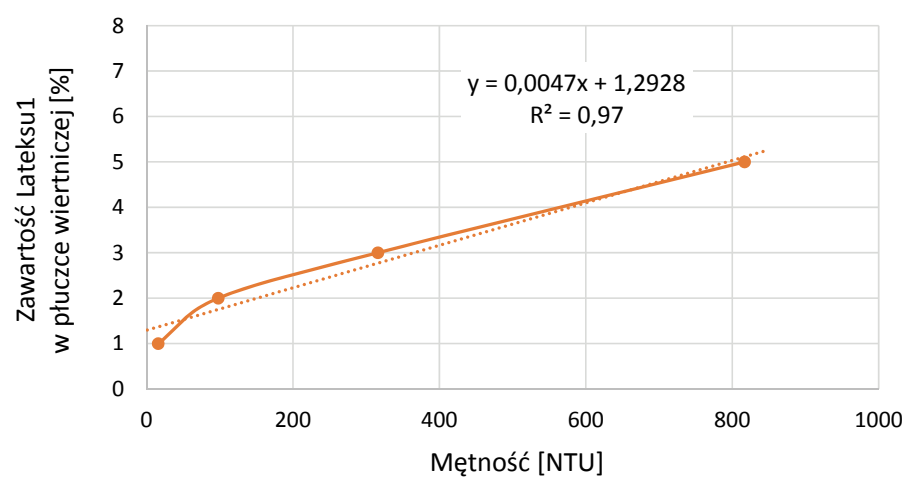

Rys. 11. Zależność mętności 10-krotnie rozcieńczonych roztworów od zawartości Lateksu1

Fig. 11. Dependence of the turbidity of 10-fold diluted suspensions on Latex1 content in the drilling muds filtrate
Tabela 12. Wyniki pomiarów mętności w zawiesinach Lateksu2 w filtratach płuczkowych

Table 12. Results of the turbidity measurements in Latex 2 suspensions in the drilling muds filtrate

\begin{tabular}{|c|c|c|c|}
\hline \multirow{2}{*}{$\begin{array}{c}\mathrm{Nr} \\
\text { pluczki }\end{array}$} & \multicolumn{2}{|l|}{ Skład cieczy } & $\begin{array}{l}\text { Mętność zawiesiny po } \\
\text { 10-krotnym rozcieńczeniu }\end{array}$ \\
\hline & \multicolumn{2}{|l|}{$[\%]$} & [NTU] \\
\hline 1 & $\begin{array}{l}\text { Biocyd } \\
\text { CMC LV } \\
\text { PAC LV } \\
\text { Ksantan } \\
\text { KCl } \\
\text { Blokator węglanowy } \\
\text { Lateks2 }\end{array}$ & $\begin{array}{c}0,1 \\
1,8 \\
0,05 \\
0,2 \\
7 \\
7 \\
\mathbf{1}\end{array}$ & 60 \\
\hline 2 & $\begin{array}{l}\text { Biocyd } \\
\text { CMC LV } \\
\text { PAC LV } \\
\text { Ksantan } \\
\text { KCl } \\
\text { Blokator węglanowy } \\
\text { Lateks2 }\end{array}$ & $\begin{array}{c}0,1 \\
1,8 \\
0,05 \\
0,2 \\
7 \\
7 \\
2\end{array}$ & 148 \\
\hline 3 & $\begin{array}{l}\text { Biocyd } \\
\text { CMC LV } \\
\text { PAC LV } \\
\text { Ksantan } \\
\text { KCl } \\
\text { Blokator węglanowy } \\
\text { Lateks2 }\end{array}$ & $\begin{array}{c}0,1 \\
1,8 \\
0,05 \\
0,15 \\
7 \\
7 \\
\mathbf{3}\end{array}$ & 218 \\
\hline 4 & $\begin{array}{l}\text { Biocyd } \\
\text { CMC LV } \\
\text { PAC LV } \\
\text { Ksantan } \\
\text { KCl } \\
\text { Blokator węglanowy } \\
\text { Lateks2 }\end{array}$ & $\begin{array}{c}0,1 \\
1,8 \\
0,05 \\
0,2 \\
7 \\
7 \\
\mathbf{5}\end{array}$ & 308 \\
\hline
\end{tabular}

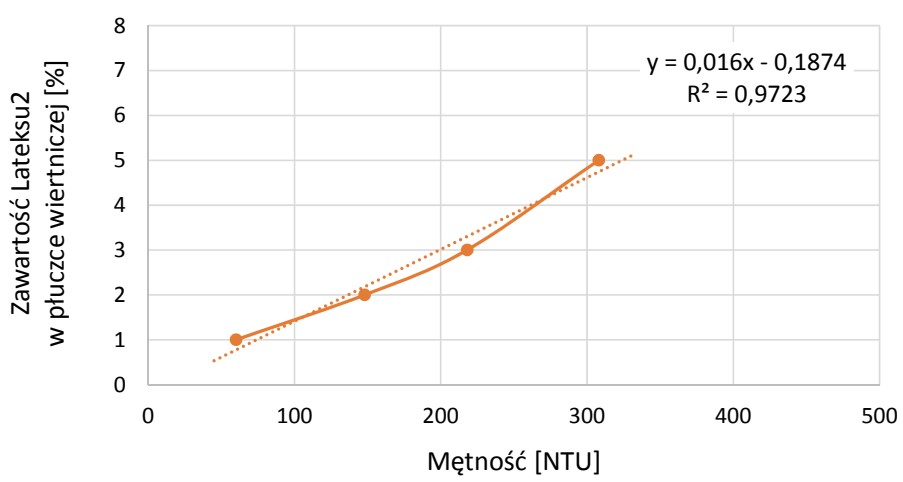

Rys. 12. Zależność mętności 10-krotnie rozcieńczonych roztworów od zawartości Lateksu2

Fig. 12. Dependence of the turbidity of 10 -fold diluted suspensions on Latex 2 content in the drilling muds filtrate 


\section{Badania płuczek wiertniczych przy wykorzystaniu opracowanych metod analitycznych}

Opracowane metody oznaczania związków aminowych i lateksów zastosowano do oznaczenia ich zawartości w płuczkach wiertniczych, których składy zebrano w tabelach 3, 4, 9, 10, 11 i 12, zawierających dodatkowo skażenia w postaci zwiercin. Kolejne dodatki zwiercin do płuczek skutkowały obniżaniem zawartości związków aminowych i lateksów w płuczkach. Wyniki uzyskanych oznaczeń przedstawiono na rysunkach 13, 14 i 15.
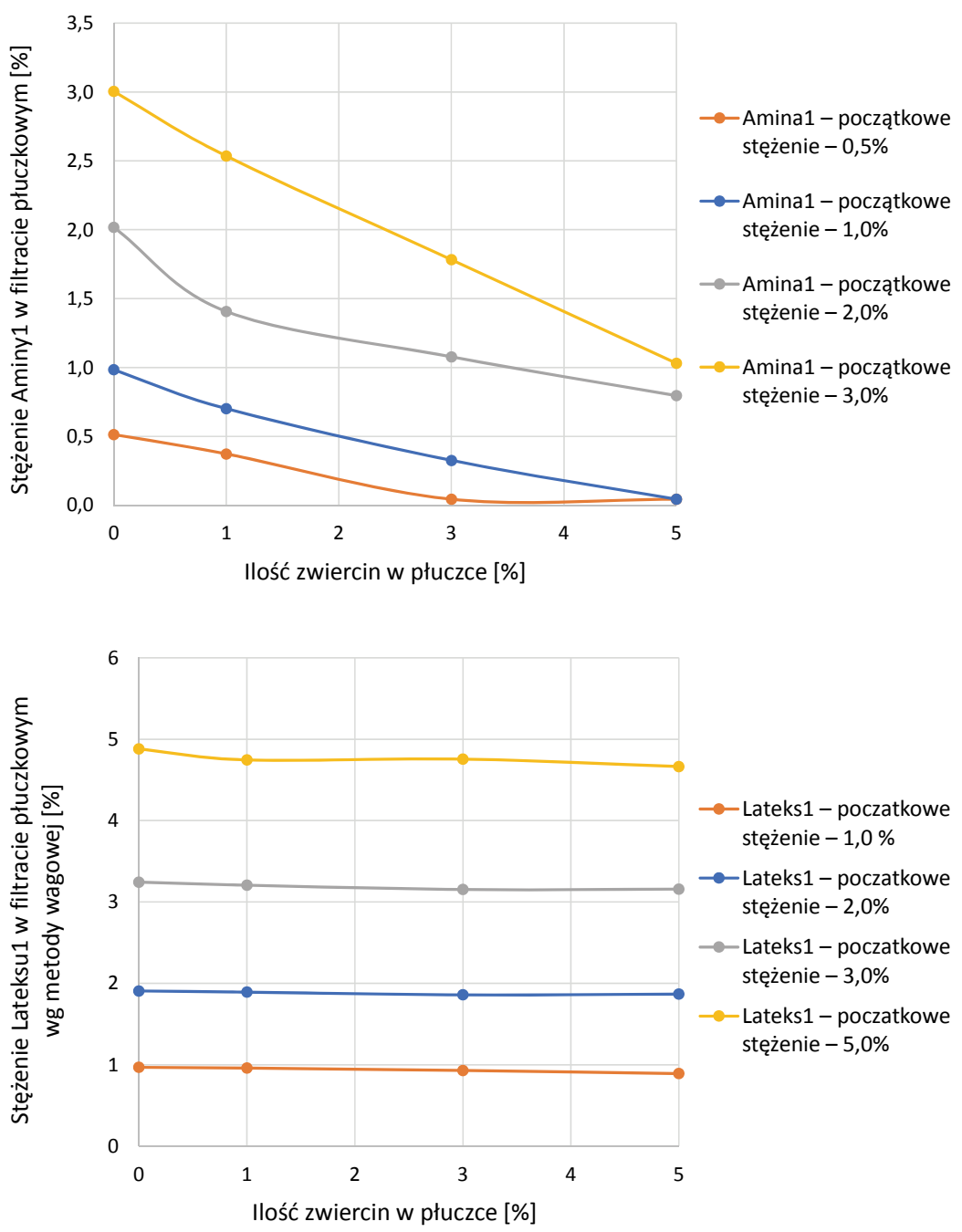

Rys. 13. Zmiany stężenia Aminy1 w zależności od ilości zwiercin w płuczce

Fig. 13. Changes in Amine1 concentration depending on the drill cuttings content

Rys. 14. Zmiany stężenia Lateksul według metody wagowej w zależności od ilości zwiercin w płuczce

Fig. 14. Changes in Latex 1 concentration according the weight method depending on the drill cuttings content

Tabela 13. Równania i wartości $\mathrm{R}^{2}$ dla poszczególnych metod analitycznych

Table 13. Equations and $\mathrm{R}^{2}$ values for individual analytical methods

\begin{tabular}{|l|c|c|}
\hline \multicolumn{1}{|c|}{ Metoda } & Równanie & \multicolumn{1}{c|}{$\mathbf{R}^{\mathbf{2}}$} \\
\hline \hline Oznaczanie związku aminowego Amina1 w roztworze wodnym & $\mathrm{y}=0,0014 \mathrm{x}+0,3969$ & 0,9986 \\
\hline Oznaczanie związku aminowego Amina1 w filtracie płuczkowym & $\mathrm{y}=0,0014 \mathrm{x}+0,1922$ & 0,9990 \\
\hline Oznaczanie związku aminowego Amina2 w roztworze wodnym & $\mathrm{y}=0,0047 \mathrm{x}-0,3327$ & 0,9986 \\
\hline Oznaczanie związku aminowego Amina2 w filtracie płuczkowym & $\mathrm{y}=0,0047 \mathrm{x}-0,6141$ & 0,9998 \\
\hline Oznaczanie lateksu Lateks1 w roztworze wodnym metodą wagową & $\mathrm{y}=43,306-0,0032$ & 0,9922 \\
\hline Oznaczanie lateksu Lateks1 w filtracie płuczkowym metodą wagową & $\mathrm{y}=48,113 \mathrm{x}-0,2679$ & 0,9904 \\
\hline Oznaczanie lateksu Lateks1 w roztworze wodnym metodą pomiaru mętności & $\mathrm{y}=0,0046 \mathrm{x}+1,1265$ & 0,9861 \\
\hline Oznaczanie lateksu Lateks1 w filtracie płuczkowym metodą pomiaru mętności & $\mathrm{y}=0,0047 \mathrm{x}+1,2928$ & 0,9700 \\
\hline Oznaczanie lateksu Lateks2 w roztworze wodnym metodą wagową & $\mathrm{y}=32,159 \mathrm{x}-0,0141$ & 0,9973 \\
\hline Oznaczanie lateksu Lateks2 w filtracie płuczkowym metodą wagową & $\mathrm{y}=32,745-0,6682$ & 0,9986 \\
\hline Oznaczanie lateksu Lateks2 w roztworze wodnym metodą pomiaru mętności & $\mathrm{y}=0,0161 \mathrm{x}+0,2813$ & 0,9928 \\
\hline Oznaczanie lateksu Lateks2 w filtracie płuczkowym metodą pomiaru mętności & $\mathrm{y}=0,0160 \mathrm{x}+0,1874$ & 0,9723 \\
\hline
\end{tabular}




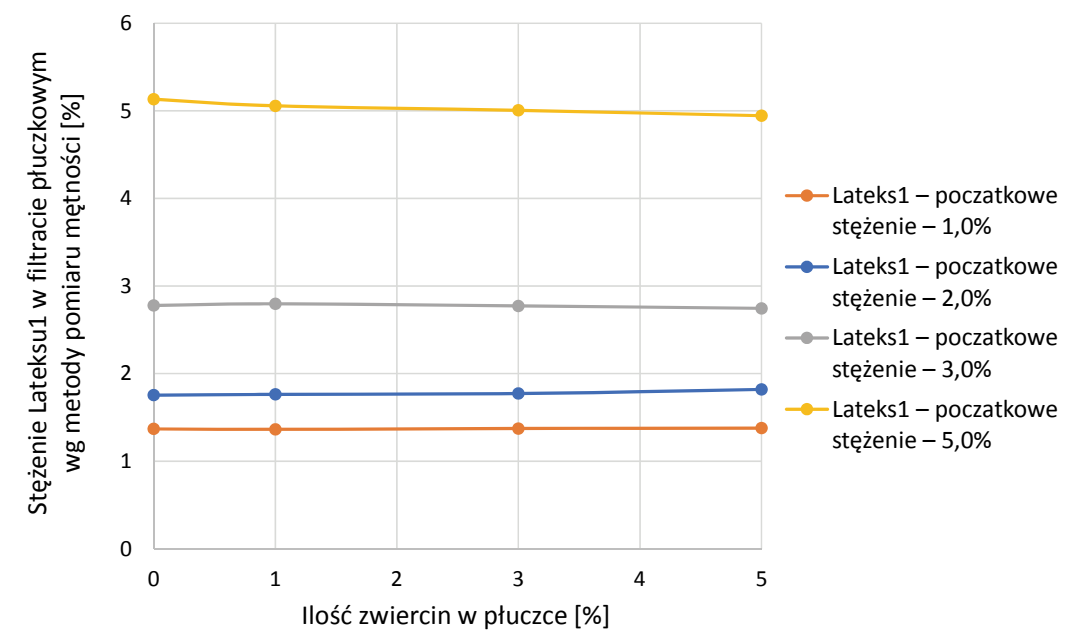

Rys. 15. Zmiany stężenia Lateksu1 według metody pomiaru mętności w zależności od ilości zwiercin w płuczce

Fig. 15. Changes in Latex 1 concentration according the turbidity method depending on the drill cuttings content

\section{Podsumowanie}

Na podstawie badań opracowano metodę oznaczania związków aminowych w płuczkach wiertniczych oraz dwie metody oznaczania lateksów. W zaproponowanych metodach połączono metody chemiczne oraz instrumentalne, takie jak pomiary nefelometryczne i fotometryczne. Wszystkie z opracowanych metod wymagają sporządzenia krzywych wzorcowych, które stanowią podstawę do obliczania zawartości danego środka w płuczce. Dla wszystkich metod opracowanych w niniejszej pracy sporządzono krzywe wzorcowe, które udało się przybliżyć liniami prostymi, w większości przy bardzo dobrych wartościach współczynnika korelacji $\mathrm{R}^{2}$. Uzyskane równania i wartości $\mathrm{R}^{2}$ zebrano w tabeli 13.

Po analizie uzyskanych równań zauważono prawidłowość, że wartości współczynnika kierunkowego otrzymanych prostych są zbliżone lub identyczne w przypadku tej samej metody przy zastosowaniu jej do roztworów wodnych i filtratów płuczkowych. Otrzymane równania różnią się tylko wartością miejsca przecięcia z osią Y, a kąt nachylenia pozostaje taki sam dla danej metody i danego środka chemicznego, na co wskazuje wartość współczynnika kierunkowego w równaniu prostej (tangens kąta nachylenia prostej).

Największe odchylenia uzyskanych wyników od rzeczywistych otrzymano dla oznaczania lateksu metodą pomiaru mętności. W przypadku tej metody uzyskano również najniższe wartości $\mathrm{R}^{2}$, które dla pomiarów w filtracie płuczkowym są w zakresie 0,9700-0,9723, a dla pomiarów w roztworach wodnych - w przedziale $0,9861-0,9928$. W przypadku większości pozostałych metod wartości $\mathrm{R}^{2}$ są zbliżone lub przewyższają wartość 0,999 .

Opracowana metoda oznaczania związków aminowych może być użyta do kontrolowania stężeń wszystkich związków zawierających azot, ponieważ jej zastosowanie jest poprzedzone mineralizacją próbki. Wymagane jest tylko sporządzenie odpowiedniej krzywej wzorcowej, nie ma znaczenia, w jakiego rodzaju grupie funkcyjnej w cząsteczce znajduje się atom azotu.

Wszystkie z opracowanych metod mogą być stosowane do monitorowania stężeń związków aminowych lub lateksów w płuczkach w czasie wiercenia zarówno w laboratorium, jak i w badaniach terenowych.

Artykuł powstał na podstawie pracy pt. Opracowanie metodyki oznaczania związków aminowych i lateksu w płuczkach wiertniczych - praca statutowa INiG - PIB na zlecenie MNiSW; nr zlecenia: 0045/KW/2020, nr archiwalny: DK-4100-0033/2020.

\section{Literatura}

Al-Ansari A., Yadav K., Anderson D., Leaper R., Dye W., Hansen N., 2005. Diverse Application of Unique High-Performance WaterBased-Mud Technology in the Middle East. Society of Petroleum Engineers. DOI: 10.2118/97314-MS.

Al-Muhailan M.S., Arun Rajagopalan A.K., Al-Shayji P.B., Jadhav F., Khatib I., 2014. Successful Application of Customized Fluid Using Specialized Synthetic Polymer in High Pressured Wells to Mitigate Differential Stikcing Problems by Minimizing Pore Pressure Transmission. IPTC-17913-MS, 1-13. DOI: 10.2523/ IPTC-17913-MS.

Balaban R.C., Vidal E.L.F., Borges M.R., 2015. Design of experiments to evaluate clay swelling inhibition by different combinations of organic compounds and inorganic salts for application in water base drilling fluids. Applied Clay Science, 105-106: 124-130. DOI: 10.1016/J.CLAY.2014.12.029.

Bielewicz D., Bortel E., 2000. Polimery w technologii płuczek wiertniczych. Uczelniane Wydawnictwa Naukowo-Dydaktyczne AGH, Kraków.

Bielewicz D., Bortel E., Witek E., 2003a. Polimery amfoteryczne w zastosowaniu do płuczek wiertniczych. Uczelniane Wydawnictwa Naukowo-Dydaktyczne AGH, Kraków.

Bielewicz D, Wysocka M., Wysocki S., 2003b. Poliamfolit poli(KAMPS-co-VAm $\cdot \mathrm{HCl}$ ) - skuteczny inhibitor hydratacji tupków. Wiertnictwo, Nafta, Gaz, 20(1): 61-68.

Błaż S., 2018. Płuczki lateksowo-glinowe do przewiercania niestabilnych formacji łupkowych. Nafta-Gaz, 7: 526-534. DOI: 10.18668/ NG.2018.07.06.

Bortel E., Witek E., Kochanowski A., 2003. Polielektrolity z merami winyloaminowymi i produkty ich modyfikacji. Przemyst Chemiczny, 82(8-9). 
Bortel E., Witek E., Kochanowski A., Pazdro M., 2005. Poliwinyloamina źródłem nowych możliwości rozwoju polimerów hydrofilowych Polimery, 50(7-8).

Bortel E., Witek E., Pazdro M., Kochanowski A., 2007. $\mathrm{N}$-winyloformamid - nowy ekologiczny monomer wodorozpuszczalny. Polimery, 52(7-8).

Chao M., Lin Z., Yuansen S., Lun L., 2014. Anti-Collapse Polyamine Aluminum Drilling Fluid System and its Application in Strong Water-Sensitive Shale Formation. EJGE, 19: 2691-2704.

Chu Q., Lin L., Zhao Y., 2019. Hyperbranched polyethylenimine modified with silane coupling agent as shale inhibitor for water-based drilling fluids. Journal of Petroleum Science and Engineering, 182: 106-133. DOI: 10.1016/j.petrol.2019.106333.

Deville J.P., Fritz B., Jarrett M., 2011. Development of water-based drilling fluids customized for shale reservoirs. SPE International Symposium on Oilfield Chemistry, The Woodlands, Texas, USA, SPE-140868-MS. DOI: 10.2118/140868-MS.

Dye B., Clapper D., Hansen N., Leaper R., Shoults L., Otto M., Xiang T., Gusler B., 2004. Design Considerations for High Performance Water-Based Muds. AADE-04-DF-HO-14: 1-11.

Dye W., Daugereau K., Hansen N., Otto M., Shoults L., Leaper R., Clapper D., Xiang T., 2005. New Water-Based Mud Balances HighPerformance Drilling and Environmental Compliance. SPE/IADC Drilling Conference, Amsterdam, Netherlands, SPE-92367-MS DOI: $10.2118 / 92367-\mathrm{MS}$.

Fernandez I.J., 2005. Evaluation of Cationic Water-Soluble Polymers With Improved Thermal Stability. SPE International Symposium on Oilfield Chemistry, The Woodlands, Texas, SPE-93003-MS. DOI: 10.2118/93003-MS

Huang J., Ghassemi A., 2010. Chemo-poroelastic Solution for Pore Pressure Transmission Test Considering Solute Diffusion. ARMA 10-337, ARMA, American Rock Mechanics Association.

Huang W., Li X., Qiu Z., Jia J., Wang Y., Li X., 2017. Inhibiting the surface hydration of shale formation using preferred surfactant compound of polyamine and twelve alkyl two hydroxyethyl amine oxide for drilling. Journal of Petroleum Science and Engineering, 159: 791-798. DOI: 10.1016/J.PETROL.2017.10.006.

Janota M., Bielewicz D., Witek E., 2002. Poliamfolit poli(KAMPS-coVAm) - nowy polimer do regulacji parametrów reologicznych i filtracji płuczek wiertniczych. Wiertnictwo, Nafta, Gaz, 19(1): 99-110.

Liu C., Hoang S.K., Tran M.H., Abousleiman Y.N., Ewy R.T., 2017. Poroelastic Dual-Porosity Dual-Permeability Simulation of Pressure Transmission Test on Chemically Active Shale. Journal of Engineering Mechanics, 143(6). DOI: 10.1061/(ASCE) EM.1943-7889.0001210.

Liu J., Qiu Z., Huang W., 2015. Novel latex particles and aluminum complexes as potential shale stabilizers in water-based drilling fluids. Journal of Petroleum Science and Engineering, 135: 433-441. DOI: 10.1016/J.PETROL.2015.10.003.

Liu J., Qiu Z., Huang W., Song D., Bao D., 2014. Preparation and Characterization of Latex Particles as Potential Physical Shale Stabilizer in Water-Based Drilling Fluids. Scientific World Journal. Article ID 895678, 1-8. DOI: 10.1155/2014/895678.

Onuoha I.E., Bilgesu H.I., Ameri S., 2011. Study of Drilling Fluid Additives and Their Impact on Smectite Inhibition, Marcellus Shale Inhibition and Filtration \& Rheological Properties of Bentonite Based Drilling Fluids. SPE Eastern Regional Meeting, Columbus, Ohio, USA, SPE-149271-MS. DOI: 10.2118/149271-MS.

Oort van E., 2003. On the physical and chemical stability of shales. Journal of Petroleum Science and Engineering, 38: 213-235. DOI: 10.1016/S0920-4105(03)00034-2.

Patel A., Stamatakis E., Friedheim J.E., Davis E., 2001. Highly Inhibitive Water-Based Fluid System Provides Superior Chemical Stabilization of Reactive Shale Formations. AADE-01-NC-HO-55.
Rea A.B., Nagatani R., Davis E.S., Carlton T., Coragliotti A., Firliet B., Tran S., 2016. A Novel System for Controlling Pore Pressure Transmission, Inhibition, Stabilization and Targeted Lubrication in Water-Sensitive Shales: Proof-of-Concept and Initial Field Results. SPE/IADC Middle East Drilling Technology Conference and Exhibition, Abu Dhabi, UAE, SPE-178215-MS. DOI: 10.2118/178215-MS.

Rzymski W. 2012. Kauczuk naturalny i wybrane produkty jego chemicznej modyfikacji - zarys historyczny. Polimery, 47: 310-315.

Schlemmer R., Friedheim J.E., Growcock F.B., Bloys J.B., Headley J.A., Polnaszek S.C., 2003. Chemical Osmosis, Shale, and Drilling Fluids. SPE Drilling \& Completion, 24(3): 318-331.

Uliasz M., 2011. Wpływ polimerów z I-rzędowymi grupami aminowymi na właściwości inhibitacyjne płuczki wiertniczej. Nafta-Gaz, 1: 19-29.

Uliasz M., Zima G., Jasiński B., Szajna A., Witek E., 2018. Ocena wpływu poliwinyloaminy na inhibitujące właściwości płuczki wiertniczej. Nafta-Gaz, 9: 669-675. DOI: 10.18668/NG.2018.09.05.

Vickers S.R., Cowie M.S., Burgess M., Anderson D.A., 2007. The Application of Specifically Formulated Bridging Materials To Successfully Reduce Pore Pressure Transmission To Enable Depleted Fractured Reservoirs To Be Drilled and Produced Without Incurring Formation Damage. European Formation Damage Conference, Scheveningen, The Netherlands, SPE-107753-MS. DOI: 10.2118/107753-MS.

Witthayapanyanon A., Leleux J., Vuillemet J., Morvan R., Pomian A., Denax A., Bland R., 2013. High Performance Water-Based Drilling Fluids - An Environmentally Friendly Fluid System Achieving Superior Shale Stabilization While Meeting Discharge Requirement Offshore Cameroon. SPE/IADC Drilling Conference, Amsterdam, The Netherlands, SPE-163502-MS. DOI: 10.2118/163502-MS.

Wu Y., Qi Q., Liang G., Zhang L., 2006. A strategy to prepare high performance starch/rubber composites: In situ modification during latex compounding process. Carbohydrate Polymers, 65(1): 109-113. DOI: 10.1016/j.carbpol.2005.12.031.

Wysocki S., Bielewicz D., Wysocka M., 2007. Badania wpływu nowo opracowanych płuczek kationowo-skrobiowych na zmianę przepuszczalności ośrodka przy użyciu filtrów ceramicznych. Wiertnictwo, Nafta, Gaz, 24(1): 627-632.

Yadav P.K., Ali S.S., Al Tawat N.A., Al Dhamen A.A., Jin G., 2016. Effect of Drilling Fluid on Rock Mechanical Properties at NearDrilling Conditions. An Implication of Fluid Design on Wellbore Stability. OTC-26460-MS, 1-9. DOI: 10.4043/26460-MS.

Young S., Stamatakis E., 2006. Novel Inhibitor Chemistry Stabilizes Shales. AADE-06-DF-HO-39.

Zhang S., Sheng J.J., Qiu Z., 2016. Water adsorption on kaolinite and illite after polyamine adsorption. Journal of Petroleum Science and Engineering, 142: 13-20. DOI: 10.1016/J.PETROL.2016.01.040.

Zhong H., Qiu Z., Huang W., Cao J., 2011. Shale inhibitive properties of polyether diamine in water-based drilling fluid. Journal of Petroleum Science and Engineering, 78: 510-515. DOI: 10.1016/J. PETROL.2011.06.003

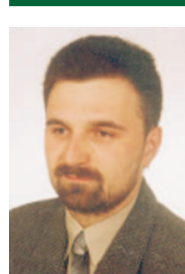

Dr inż. Grzegorz ZIMA

Adiunkt w Zakładzie Technologii Wiercenia Instytut Nafty i Gazu - Państwowy Instytut Badawczy ul. Lubicz $25 \mathrm{~A}$ 31-503 Kraków E-mail: grzegorz.zima@inig.pl 